\title{
Non-syndromic brachydactyly, known as Shamoji-yubi or Mamushi-yubi in Japan
}

Takeshi Saraya, ${ }^{1}$ Masae Ariga, ${ }^{2}$ Aika Kato, ${ }^{2}$ Hajime Goto ${ }^{1}$

${ }^{1}$ Department of Respiratory Medicine, Kyorin University, Mitaka, Japan

${ }^{2}$ Department of General Medicine, Jiundo Naika Hospital, Nerima, Tokyo, Japan

\section{Correspondence to}

Dr Takeshi Saraya, sara@yd5.so-net.ne.jp
To cite: Saraya T, Ariga M, Kato $A$, et al. BMJ Case Rep Published online: [please include Day Month Year] doi:10.1136/bcr-2013201242

\section{DESCRIPTION}

A 67-year-old previously healthy woman was referred following an annual physical check-up.
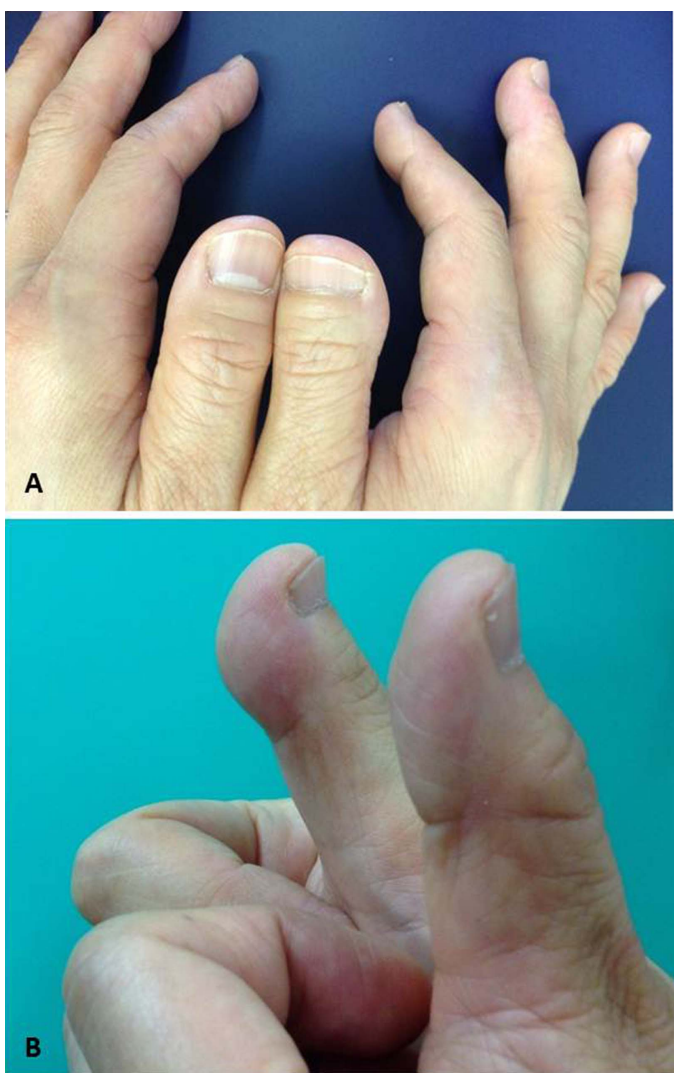

Figure 1 Short distal phalanx of the right thumb with broad tip was noted (A) and the pulp of the right thumb is larger than that of the left (B).
Physical examination was normal except for a short distal phalanx (SDP) of the right thumb with a broad tip (figure 1A). Furthermore, on the lateral view (figure 1B), the pulp of the right thumb was larger than that of the left, and had the appearance of a viper. Interestingly, her family pedigree showed that the inheritance pattern was a single autosomal dominant gene with incomplete penetrance (figure 2), and individuals had brachydactyly only in their thumb with unilateral or bilateral expression. In Japan, this brachydactyly is not rare, and is usually called Mamushi-yubi (a viper) or Shamoji-yubi (a flat rice paddle used in Japanese cooking).

Although genetic assessment was not performed, this case was morphologically diagnosed as brachydactyly type $\mathrm{D}(\mathrm{BDD})^{1}{ }^{2}$ which is associated with missense mutations in the homeodomain of homeobox d13 (HOXD13). The prevalence of BDD ranges from $0.41 \%$ to $4 \%$ in various populations, with a particularly high prevalence among Israeli Arabs and the Japanese population. BDD is characterised by bilateral or unilateral SDP of the thumb of various degrees, and results in a broad, greatly shortened nail. SDP of the thumb may be associated with acrocephalopolysyndactyly, Apert syndrome, Christian syndrome, fibrodysplasia ossificans progressiva, hand-foot-genital syndrome, otopalatodigital syndrome type 1, pseudohypoparathyroidism, pseudopseudohypoparathyroidism or other congenital diseases. However, the absence of short stature, mental retardation and an abnormal head shape ${ }^{3}$ would suggest a diagnosis of BDD as an isolated malformation in most cases.

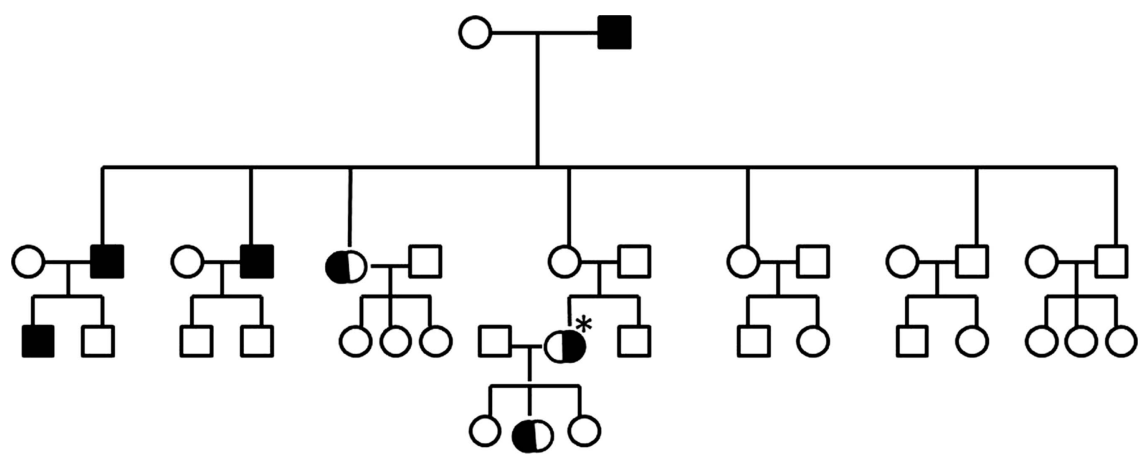

Figure 2 Pedigrees of brachydactyly (type D) in the patient's family. Shading of complete circles and squares indicates bilateral expression; shading of a right half or left half indicates unilateral expression on that side. Squares indicate males, circles indicate females. 


\section{Learning points}

- Non-syndromic brachydactyly looking like a 'viper' or 'rice paddle' in one or both thumbs suggests brachydactyly type $\mathrm{D}(\mathrm{BDD})$.

- The prevalence of BDD ranges from $0.41 \%$ to $4 \%$ in various populations, but it is highly prevalent in Israeli Arabs and the Japanese population.

- The absence of short stature, mental retardation and an abnormal head shape would suggest a BDD as an isolated malformation.
Contributors TS and HG wrote the manuscript. MA and AK managed the patient in the outpatient department.

Competing interests None.

Patient consent Obtained.

Provenance and peer review Not commissioned; externally peer reviewed.

\section{REFERENCES}

1 Gray E, Hurt VK. Inheritance of brachydactyly type D. J Hered 1984;75:297-9.

2 Mundlos S. The brachydactylies: a molecular disease family. Clin Genet 2009;76:123-36.

3 Villaverde MM, Da Silva JA. Distal brachyphalangy of the thumb in mental retardation. J Med Genet 1975:12:401-4

Acknowledgements The authors would like to thank Dr Takao Ito for his useful advice on morphological assessment.

Copyright 2013 BMJ Publishing Group. All rights reserved. For permission to reuse any of this content visit http://group.bmj.com/group/rights-licensing/permissions.

BMJ Case Report Fellows may re-use this article for personal use and teaching without any further permission.

Become a Fellow of BMJ Case Reports today and you can:

- Submit as many cases as you like

- Enjoy fast sympathetic peer review and rapid publication of accepted articles

- Access all the published articles

- Re-use any of the published material for personal use and teaching without further permission

For information on Institutional Fellowships contact consortiasales@bmjgroup.com

Visit casereports.bmj.com for more articles like this and to become a Fellow 